\title{
WAKAF PRODUKTIF DALAM PEMBERANTASAN KEMISKINAN MELALUI PEMBERDAYAAN EKONOMI DI YAYASAN NURUL HAYAT SURABAYA ${ }^{11}$
}

\author{
Azwar Anas \\ Mahasiswa Program Studi S1 Ekonomi Islam-Fakultas Ekonomi dan Bisnis-Universitas Airlangga \\ Email : azwar.anas-12@feb.unair.ac.id \\ Muhammad Nafik Hadi Ryandono \\ Departemen Ekonomi Syariah-Fakultas Ekonomi dan Bisnis-Unversitas Airlangga \\ Email : muhammadnafik@feb.unair.ac.id
}

\begin{abstract}
:
This research aims to determining how the management of waqf productive economic empowerment of the poor. The results showed that the Yayasan Nurul Hayat Surabaya have conducted productive endowments that participate in empowering the poor economy in the city of Surabaya. Endowments managed productively channeled through several programs among which Matabaca and also Bunda Yatim. Economic empowerment strategy taken in the management of productive endowments made through the approach of the religious side. Before accepting funding capital endowments, beneficiaries are required to attend regular lectures held Yayasan Nurul Hayat Surabaya within a period of 1 year. Endowment fund so that recipients are not only more economically independent, but also increased in terms of religion.
\end{abstract}

Keywords: productive endowments, economic empowerment, the poor, Yayasan Nurul Hayat Surabaya

\section{PENDAHULUAN}

Wakaf adalah salah satu sumber keuangan publik yang mampu mengangkat derajat kehidupan perekonomian ummat. Wakaf merupakan suatu amalan dalam Islam yang berperan baik secara ekonomi maupun sosial yang digunakan sebagai pengembangan kehidupan manusia dalam mencapai kesejahteraan masyarakat yang adil dan makmur. Wakaf dapat dibedakan menjadi dua jenis, yaitu wakaf produktif dan wakaf konsumtif (Non Produktif). Wakaf konsumtif atau non produktif yaitu harta benda tetapnya wakaf digunakan langsung untuk kepentingan umat. Seperti halnya di Indonesia saat ini bahwa wakaf ini di gunakan untuk masjid, sekolah, tempat pemakaman, dll. Jika dilihat dari sisi sosial, memang hal ini cukup efektif, namun dampaknya ialah akan berpengaruh pada segi ekonomi di masyarakat. Sehingga perlu adanya kesinambungan dengan wakaf yang dikelola secara produktif agar tingkat kesejahteraan masyarakat dapat terealisasikan secara maksimal.

Perkembangan wakaf cukup kondusif khususnya di daerah timur tengah pada saat ini. Di Negara-negara Muslim, wakaf telah dikelola dengan sangat baik sehingga meningkaatkan kesejahteraan ekonomi umat khusunya umat islam. Seperti misalnya di Mesir, Universitas AlAzhar di Kairo telah menjalankan aktivitasnya dengan dana wakaf. Universitas tersebut telah mengelola 
perusahaan di Terusan Suez. Universitas AlAzhar selaku nadzir mengambil hasilnya hanya untuk keperluan pendidikan. Bahkan pemerintahan di Mesir meminjam dana wakaf Al-Azhar untuk operasional. Selain itu di Qatar dan Kuwait, dana wakaf sudah berbentuk bangunan perkantoran. Bangunan tersebut disewakan dan keuntungannya digunakan untuk kegiatan umat muslim. Mereka dapat bertahan hingga saat ini walaupun tidak berorientasi pada profit semata dan juga tidak mengandalkan bantuan dari pemerintah, melainkan pada wakaf tunai sebagai pembiayaan aktivitas akademik maupun administratif. Sehingga wakaf tunai menjadi instrument ekonomi bagi pengembangan mereka.

Indonesia sendiri adalah penggunaan wakaf masih cenderung jauh dari perhatian masyarakat dan hanya identik dengan masjid, tempat pemakaman, sekolah, pondok pesantren, dan fasilitas lainnya. Sedangkan wakaf yang diperuntukkan dalam hal peningkatan kesejahteraan umat di bidang ekonomi masih sangat minim sehingga dapat dikatakan wakaf di Indonesia bersifat konsumtif, bukan produktif (Depag Rl, 2004:36-37).

Munculnya paradigma wakaf produktif menjadikan sebuah momentum Suatu upaya perubahan dari pengelolaan wakaf produktif yang tradisional menjadi pengelolaan wakaf yang proesional dalam meningkatkan dan member manfaat wakaf (Mubarok, 2008:16). Paradigma wakaf produktif lebih diarahkan untuk pengembangan harta wakaf dan memaksimalkan potensi wakaf di bidang ekonomi. Menurut Muhammad Syafi'i Antonio, pemberdayaan wakaf ditandai dengan ciri utama, yaitu pola manajemen wakaf harus terintegrasi, asas kesejahteraan nazir serta asas transformasi serta tanggung jawab (Mubarok, 2008:3536).

$$
\text { Wakaf dalam Peraturan }
$$
Pemerintah nomor 28 tahun 1977 adalah perbuatan hukum seseorang atau badan hikum yang memisahkan sebagian dari harga kekayaannya yang berupa tanah milik dan melembagakannya untuk selama-lamanya untuk kepentingan peribadatan atau keperluan umum lainnya sesuai dengan ajaran islam.

Pengelolaan wakaf secara produktif sesungguhnya telah diatur oleh pemerintah dalam Undang-Undang Republik Indonesia Nomor 41 Tahun 2004 tentang Wakaf, yaitu antara lain disebutkan dalam Dahwan (2008:73) bahwa :

"Peruntukkan benda wakaf tidak semata-mata untuk sarana kepentingan ibadah dan sosial, melainkan diarahkan pula untuk mewujudkan kesejahteraan umum dengan cara meningkatkan potensi dan manfaat ekonomi benda wakaf. $\mathrm{Hal}$ ini memungkinkan pengelolaan benda wakaf dapat memasuki wilayah kegiatan ekonomi dalam arti luas sepanjang pengelolaan tersebut sesuai dengan prinsip-prinsip manajemen dan ekonomi syariah"

Pernyataan tersebut dapat dikatakan bahwa pengelolaan wakaf harus dilakukan secara optimal agar dapat 
memberi manfaat bagi masyarakat. Dalam perwujudannya, pengelolaan wakaf harus dijalankan dengan melakukan kegiatan ekonomi agar dapat mensejahterakan umat manusia. Kegiatan ekonomi dalam pengelolaan wakaf harus sesuai dengan prinsip-prinsip ekonomi syariah. Undang-undang ini juga mewajibkan nadzir sebagai pengelola wakaf untuk mengadministrasi, mengelola, mengembangkan, mengawasi, dan melindungi harta wakaf. Dan juga membuat laporan secara berkala kepada Menteri Agama mengenai kegiatan wakaf. Kemudian pada UU Nomor 42 Tahun 2006 menjelaskan tentang pelaksanaan ini.

Potensi wakaf di Indonesia yang begitu besar sangat memungkinkan untuk dikelola secara produktif. Pengelolaan wakaf saat ini bisa dilakukan oleh pihak perorangan, organisasi, dan berbadan hukum. Salah satu pengelola wakaf ada yayasan Nurul Hayat Surabaya. Yayasan Nurul Hayat berdiri pada tahun 2001, bergerak dalam bidang layanan sosial dan dakwah. Nurul Hayat sejak awal didirikan sudah dicita-citakan untuk lembaga milik masyarakat yang mandiri.

Berdasarkan paparan diatas, peneliti tertarik untuk meneliti masalah tersebut karena hasil penilitian ini dibutuhkan banyak elemen, mulai dari pengelola wakaf sendiri, para pelajar ataupun masyarakat yang ingin mengerti lebih jauh tentang wakaf. Oleh karena itu, Penelitian ini terfokus pada "Pengelolaan Wakaf Produktif dalam Pemberdayaan
Ekonomi Masyarakat". Obyek Penelitian yang dipilih oleh peneliti ialah Yayasan Nurul Hayat Surabaya, dikarenakan Yayasan tersebut telah melaksanakan kegiatan wakaf secara produktif di bidang ekonomi.

\section{LANDASAN TEORI}

Wakaf secara etimologi berasal dari bahasa arab "waqafa" yang berarti menahan atau mencegah. Sebagai kata benda, kata "waqf" semakna dengan kata "al-habs" yang artinya sama-sama mencegah, atau sesuatu yang ditahan. Jadi, jika berbicara masalah wakaf berarti dari aset atau harta seseorang atau kaum muslimin yang diperuntukkan untuk kemaslahatan umat untuk diambil benefit atau keuntungannya dan pokoknya yang ditahan (Hadi, 2009:15).

Halim (2005:7), wakaf ialah menyerahkan hak milik yang zatnya dapat bertahan lama kepada seseorang ataau nazhir (orang yang mengurus wakaf) atau kepada badan pengelola dengan ketentuan yaitu hasil dan manfaatnya digunakan sesuai ketentuan Islam dan benda yang telah diwakafkan nantinya bukan lagi menjadi hak milik wakif (orang yang mewakafkan) maupun tempat yang menyerahkan, melainkan menjadi milik Allah SWT.

Pendapat para ulama tentang pengertian wakaf pun berbeda-beda sesuai dengan mahzab yang dianut. Definisi wakaf menurut para ahli figh dalam Lubis akk (2010:4-7) diantaranya ialah :

1. Menurut Mazhab Hanafi, wakaf yaitu menahan benda wakif (orang yang 
mewakafkan) dan menyedekahkan manfaatnya kepada siapa saja untuk tujuan kebaikan. Hal tersebut menjelaskan bahwa aset seseorang yang telah diwakafkan akan tetap ditahan dan kepemilikan hartanya masih menjadi hak mutlak bagi wakif.

2. Menurut Mazhab Hambali, wakaf ialah menahan secara mutlak kebebasan pemilik harta untuk menjalankan hartanya yang bermanfaat dengan keutuhan hartanya dan memutuskan seluruh hak penguasaan terhadap harta, namun manfaatnya ialah demi kebaikan dalam mendekatkan diri kepada Allah SWT. Harta wakaf juga tidak boleh diperjualbelikan, di hibahkan, maupun diwariskan kepada siapa saja. Hal ini menjelaskan apabila harta tersebut telah diwakafkan oleh wakif, maka hak atas kepemilikan wakif tersebut akan hilang.

3. Mazhab Syafi'l menjelaskan, wakaf berarti menahan harta yang dapat diambil manfaatnya dan harta tersebut tetap merupakan barang yang utuh yang kemudian kepemilikan atas barang tersebut akan hilang dari wakif, dan hanya dapat dimanfaatkan pada sesuatu yang diperbolehkan. Ini menjelaskan bahwa apabila pemindahan harta yang telah diwakafkan oleh wakif kepada nazhir, maka harta tersebut beralih untuk dimanfaatkan untuk kepentingan masyarakat.

4. Menurut Mazhab Maliki, wakaf dapat menjadikan manfaat harta kepada wakif yaitu berupa sewa yang nanti hasilnya akan diberikan kepada yang berhak menerimanya sesuai kehendak dari wakif. Jadi, harta yang telah diwakafkan oleh wakif akan tetap menjadi miliknya. Namun, hanya manfaatnya saja yang diwakafkan bukan keutuhan barangnya.

Wakaf dalam Islam dijelaskan secara eksplisit atau tidak disebutkan secara langsung. Kata "wakaf" dalam AlQuran memang tidak disebutkan secara tegas. Namun maknyanya mengandung pengertian mengenai wakaf dan juga perbuatan wakaf merupakan telaah dari Rasulullah SAW dan para sahabat.

Wakaf dapat dibedakan menjadi dua macam dalam Dirjen Bimas Islam (2007:14), Antara lain yaitu:

1. Wakaf Ahli/ wakaf dzurri

Wakaf dzurri yaitu wakaf yang ditujukan untuk orang-orang tertentu baik yang merupakan dari keluarga wakif atau bukan. Wakaf ini juga dapat disebut sebagai wakaf 'alal aulad yang berarti wakaf yang diperuntukkan di lingkungan keluarga maupun kepentingan-kepentingan tertentu sebagai jaminan sosial. Namun manfaatnya dianggap kurang dikarenakan memberikan ketidakpastiaan dalam pengelolaannya.

2. Wakaf khairi

Wakaf khairi adalah wakaf yang digunakan untuk kepentingan agama dan kemaslahatan umat. Wakaf jenis ini dianggap dapat memberikan 
banyak manfaat daripada wakaf lainnya. Hal ini dikarenakan wakaf khairi dirasa memiliki lebih banyak manfaat.

Menurut isfandiar (2008:61) mengatakan:

"Kedua macam wakaf ini memiliki aspek-aspek kebaikan tersendiri yaitu kebaikan dalam hal amal ibadah dan kebaikan dalam menjalin tali silaturahmi terhadap masyarakat maupun keluarga yang diberikan harta dari wakaf ini. Tetapi di sisi lain, wakaf dzurri menimbulkan beberapa pertentangan yaitu apabila keturunan yang ditunjuk oleh wakif sudah tidak ada maka akan terjadi ketidakpastian dalam hal kepada siapa harta tersebut diberikan untuk diambil manfaat hartanya".

Wakaf dalam Dirjen Bimas Islam (2007:21)dapat dikatakan sah apabila terpenuhi unsur-unsur wakaf seperti berikut:

1. Wakif, Yaitu orang yang mewakafkan harta.

2. Mauquf bih, Yaitu harta yang diwakafkan.

3. Mauquf 'alaih, pihak yang diberi atau diperuntukkan wakaf.

4. Sighat, ikrar dari wakif untuk suatu kehendak dalam mewakafkan sebagian hartanya.

Wakaf tidak hanya sebagai hal yang dianjurkan dalam ajaran Islam, tetapi wakaf memiliki banyak manfaat bagi seluruh masyarakat. Diantara manfaat dari wakaf dalam Hafidhuddin (2007:161) yaitu:

1. Menunjukkan nilai kepedulian dan tanggung jawab dalam kebutuhan masyarakat. Wakaf dapat membantu masyarakat yang sangat membutuhkan dengan memberikan sebagan harta benda kita agar menolong kehidupan mereka dan terhindar dari kemiskinan.

2. Memberikan keuntungan moril bagi wakif sehingga pahal yang didapatkan akan mengalir terus meskipun wakif meninggal dunia. Harta yang telah diberikan oleh wakif akan terus dimanfaatkan oleh nadzir untuk kepentingan umat sehingga amalan wakaf tersebut tidak akan pernah putus.

3. Memperbanyak harta yang dipergunakan untuk kepentingan masyarakat luas sesuai ketentuan syariah. Wakaf dapat memberikan kehidupan mandiri kepada masyarakat karena manfaat yang diperoleh sangat banyak sehingga tidak perlu bergantung pada anggaran pemerintah sehingga juga dapat membantu pemerintah untuk membantu mensejahterakan masyarakat.

4. Sumber dana yang berpotensi bagi peningkatan kualitas umat, seperti pendidikan, kesehatan, kesejahteraan, dan sebagainya. Wakaf merupakan unsur yang relevan dalam hal investasi jangka panjang karena potensi harta yang dimanfaatkan pun juga sangat banyak yang kemudian nantinya akan disalurkan kepada masyarakat yang membutuhkan.

Lembaga wakaf merupakan badan yang mengelola perpindahan harta kepemilikan dari wakif selaku pemberi harta kepada nadzir selaku 
pengelola baik berupa dana, tanah, maupun benda lainnya (benda bergerak maupun tidak bergerak) yang hasilnya akan disalurkan kepada masyarakat luas.

Wakaf adalah salah sektor yang cukup memiliki peran besar dalam pemberdayaan ekonomi masyarakat. Wakaf sangat berperan penting dalam pengembangan sosial, ekonomi, dan budaya. Salah satu peran yang cukup memberikan pengaruh besar adalah dibidang pendidikan dan kesehatan. Praktek pengelolaan wakaf produktif telah dilakukan dengan baik di Negara-negara timur tengah seperti Mesir, Arab Saudi, Turki dan lainnya. Negara-negara tersebut mampu melakukan pembangunan sarana dan prasarana dari hasil pengembangan wakaf.

Tujuan dan kontribusi dari institusi wakaf uang memiliki keberadaan yang sangat krusial. Menurut Agustianto (2010:29), ada beberapa hal yang mengakibatkan pentingnya pemberdayaan wakaf di Indonesia:

1. Angka kemiskinan di Indonesia masih tinggi, yang perlu mendapat perhatian dan lankah-langkah yang konkrit.

2. Kesenjangan yang tinggi antara penduduk kaya dan miskin.

3. Indonesia memiliki jumlah penduduk Muslim terbesar, sehingga wakaf memiliki potensi yang besar untuk dikembangkan.

4. Sejumlah bencana yang terjadi mengakibatkan terjadinya deficit APBN, sehingga diperlukan kemandirian masyarakat dalam pengadaan public goods.

Berbagai macam pengeloaan wakaf produktif bisa dilakukan, diantaranya adalah menggunakan beberapa akad (Dahwan, 2008:75):

a. al ijarah (operational lease) atau lebih dikenal dengan perjanjian sewa menyewa. Al ijarah dalam pengelolaan wakaf produktif nadhir adalah pihak pertama sebagai pihak yang menyewakan, sedang penyewa adalah pihak kedua yang mengambil manfaat barang yang disewa dengan kewajiban memberi imbalan yang besarnya telah disepakati kepada pihak pertama.

b. ijarah al 'amal yakni dengan perjanjian perburuhan, maksudnya dimana penyewa dan pihak yang disewa melakukan akad sewa terhadap jasa tenaga kerja untuk melakukan suatu pekerjaan dengan upah atau gaji yang telah disepakati.

c. al ijarah al muntahiyah bi al tamlik (financial lease with purchase option) yaitu dengan perjanjian sewa menyewa yang berakhir dengan pemilikan atas barang yang disewa. Akad ini lebih dikenal dengan perpaduan kontrak jual beli dan sewa atau sewa yang diakhir dengan kepimilikan barang ditangan penyewa. Pemindahan kepemilikan inilah yang membedakan dengan ijarah pada umumnya. (Syafi'l, 2001:118) 
d. al murabahah (deferred payment sale) yaitu dengan perjanjian jual beli dengan keuntungan yang disepakati. Akad ini dalam pengelolaan benda wakaf dapat dilakukan dengan membuat perjanjian antara nadhir yang bertindak sebagai pembeli dengan pihak lain yang bertindak sebagai penjual. Contoh kaitan hal ini adalah lembaga kevangan syariah selaku penyandang dana, yang melakukan pengadaan barang dan sekaligus sebagai penjual.

e. al mudarabah (trust financing, trust investment) yakni dengan perjanjian bagi hasil keuntungan perniagaan. Akad ini adalah kerjasama usaha diantara dua pihak, dimana pihak pertama sebagai penyedia modal penuh, dan pihak kedua adalah sebagai pengelola. Dalam pengelolaan wakaf produktif pihak pertama bertindak sebagai nadhir yang akan menyerahkan seluruh modal kepada pengelola atau mudharib. Keuntungan yang diperoleh dibagi sesuai kesepakatan, keuntungan ini yang kemudian ditasharufkan sesuai tujuan wakaf.

f. al musyarakah (partnership, project financing participation) yakni dengan perjanjian kerjasama dalam persekutuan dagang dan yang terakhir. Dalam pengelolaan benda wakaf produktif, nadhir akan berkedudukan sebagai salah satu pihak dalam penyelenggaraan perjanjian musyarakah ini. Nadhir akan menyerahkan sejumlah harta, begitu pula dengan yang lainnya. Dana ini kemudian disatukan untuk dijadikan modal bersama. Perjanjian ini memiliki resiko yang cukup tinggi dibandingkan yang lain, karen nadhir harus hati-hati dan jeli dalam memilih rekan untuk diajak bergabung terlebih usaha ini ditujukan sebagai pengelolaan benda wakaf produktif.

g. al muzara'ah (harvest-yield profit sharing) yakni dengan perjanjian bagi hasil pertanian. Jika lahan pertanian tersebut merupakan benda wakaf maka pemilik lahan merupakan nadhir dan pihak lainnya adalah pengelola. Pembagian hasil menurut kesepakatan dan harus didasarkan kepada keadilan dan pertimbangan yang baik.

Menurut Mubyarto (1997: 37) pemberdayaan ekonomi masyarakat dapat dilihat dari tiga sisi:

1. Menciptakan suasana yang memungkinkan potensi masyarakat berkembang. Titik tolak pemikirannya adalah pengenalan bahwa setiap manusia, dan setiap masyarakat, memiliki potensi yang dapat dikembangkan, tidak ada masyarakat yang sama sekali tanpa daya.

2. Memperkuat potensi masyarakat dengan peningkatan taraf pendidikan, derajat kesehatan serta terbukanya kesempatan untuk memanfaatkan peluang ekonomi. 
3. Mengembangkan ekonomi masyarakat juga memiliki arti melindumgi rakyat dan mencegah terjadinya persaingan yang tidak seimbang eksploitasi golongan ekonomi yang kuat atas yang lemah.

Berdasarkan landasan teori yang telah dijelaskan, maka dapat dirancang kerangka berpikir sbagai berikut:

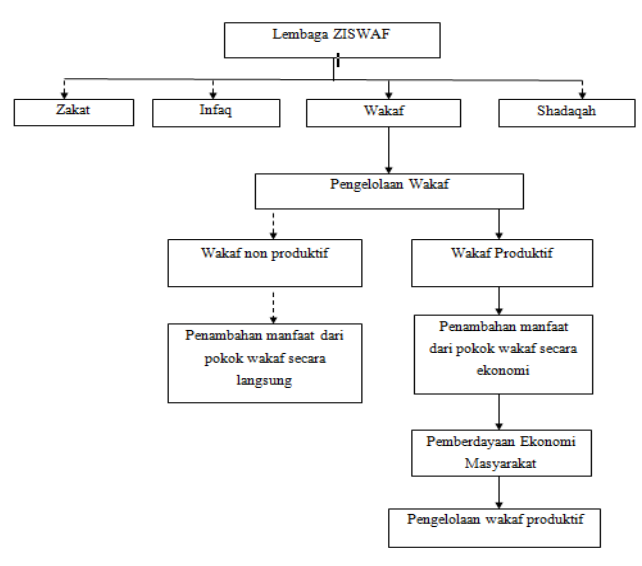

Gambar 1.

Kerangka Berpikir

\section{METODE PENELITIAN}

\section{Pendekatan Penelitian}

Penelitian ini menggunakan pendekatan penelitian kualitatif. Dimana data yang terkumpul akan diolah dan dianalisis secara deskriptif. Penelitian kualitatif merupakan penelitian yang menekankan pada proses yaitu tidak menjadikan hasil penelitian sebagai orientasi keberhasilan suatu data melainkan kebenaran dari hipotesis yang disajikan melalui hasil penelitian gejala sosial yang ada. Menurut Yin (2009; 2) pendekatan kualitatif adalah pendekatan dengan menggunakan data yang berupa kalimat tertulis atau lisan, peristiwaperistiwa, pengetahuan yang bersifat deskriptif.

\section{Ruang Lingkup Penelitian}

Penelitian yang dimaksud adalah untuk menjawab rumusan masalah "Bagaimana pengelolaan wakaf produktif dalam pemberdayaan ekonomi Masyarakat ?". Rumusan masalah tersebut yang akan menjadi acuan bagi peneliti untuk menentukan ruang lingkup penelitian. Penelitian ini dilakukan di Lembaga Amil Zakat Nurul Hayat Surabaya. Nurul Hayat termasuk salah satu lembaga yang telah mengelola dana wakaf disamping dana zakat, shodaqoh dan lainnya.

\section{Obyek dan Subyek Penelitian}

Peneliti menjelaskan maksud dan tujuan penelitian kepada ketua Yayasan Nurul Hayat Surabaya, kemudian melakukan observasi secara langsung bagaimana proses pemberdayaan ekonomi masyarakat oleh Yayasan Nurul Hayat Surabaya. Peneliti juga melakukan wawancara yang mendalam pada pihakpihak terkait lainnya. Hal ini dilakukan beberapa hari secara terus-menerus secara berkala sampai peneliti mendapatkan jawaban dari rumusan masalah yang telah dibuat sebelumnya.

\section{Narasumber}

Pada penelitian ini, yang menjadi narasumber utama adalah ketua pimpinan Yayasan Nurul Hayat Surabaya, ketua atau koordinator bagian pengelola dana wakaf Nurul Hayat, dan beberapa 
Anas, et al/Jurnal Ekonomi Syariah Teori dan Terapan Vol. 4 No. 3 Maret 2017: 253-268; WAKAF PRODUKTIF DALAM PEMBERANTASAN KEMISKINAN MELALUI PEMBERDAYAAN EKONOMI DI YAYASAN NURUL HAYAT SURABAYA

warga yang telah merasakan manfaat dari wakaf yang telah dikelola oleh Nurul Hayat.

\section{Jenis dan Sumber Data}

Sumber data merupakan hal yang paling penting di dalam proses penelitian. Sumber data yang relevan merupakan cerminan dari integritas informasi yang ada di dalam penelitian. Pada penelitian ini, sumber data yang digunakan adalah data primer dan data sekunder.

\section{Teknik Pengumpulan Data}

Teknik pengumpulan data yang dilakukan di dalam penelitian ini adalah wawancara mendalam (in-depth interview), observasi partisipan, dan studi dokumentasi.

\section{Teknik Analisis Data}

Teknik yang digunakan untuk pengujian keabsahan data adalah triangulasi sumber. Teknik triangulasi sebagai teknik untuk mengecek keabsahan data, dimana dalam pengertiannya triangulasi adalah teknik pemeriksaan keabsahan data yang memanfaatkan sesuatu yang lain dalam membandingkan hasil wawancara terhadap objek penelitian. Triangulasi dengan sumber artinya membandingkan dan mengecek balik derajat kepercayaan suatu informasi yang diperoleh melalui waktu dan alat yang berbeda dalam penelitian kualitatif (Patton, 1987:331).

\section{HASIL DAN PEMBAHASAN}

\section{Sistem Pengelolaan Wakaf Produktif}

Program BMT Pilar Mandiri yang dikelola oleh YNHS menganut sistem wakaf modal yaitu dengan cara meminjamkan sejumlah dana kepada pihak-pihak yang membutuhkan, kemudian dana tersebut dijadikan modal usaha yang menghasilkan keuntungan. Dalam sistem perekonomian modern, distribusi harta wakaf yang dimanfaatkan dalam kegiatan produktif, implikasinya tentu akan menggerakkan aktivitas ekonomi masyarakat secara menyeluruh. YNHS memiliki enam jenis program yang dijalankan sejak tahun 2012 , kecuali Bunda Yatim yang baru dijalankan tahun 2013. Program-program tersebut diantaranya yaitu Sayang, Matabaca, Ibuqu, Bunda Yatim, Tafakur dan Praktis. Sayang (Santunan Bunda Yatim Cemerlang), merupakan program bantuan pendidikan gratis di pondok pesantren Nurul Hayat bagi anak yatim, diketahui dari data sekunder selama tiga tahun terus mengalami peningkatan penyaluran dana. MATABACA (Majelis Ta'lim Abang Becak), memberikan bantuan kepada abang becak, baik dari segi ekonomi maupun pengetahuan agamanya, diketahui bahwa penyaluran dana untuk program ini mengalami kenaikan yang signifikan dari tahun ke tahun. IBUQU (Insentif Bulanan Guru AlQuran), memberikan pendidikan khusus kepada yang kurang mampu agar bisa mengajar Al-Quran pada anak-anak, dalam perjalanannya program ini juga mendapatkan penyaluran dana yang terus mengalami kenaikan setiap tahunnya. Bunda yatim, memberikan bantuan bagi janda yang tidak mampu. TAFAKUR (Tanda Cinta Penghafal Alquran), memberikan modal usaha dalam bentuk 
barang kepada para penghafal Al-Quran, penyaluran dana untuk program ini mengalami penurunan terus-menerus dari tahun ke tahun, hal tersebut dimungkinkan karena semakin berkurangnya jumlah penghafal Al-Quran. Praktis (Praktek Medis) atau biasa disebut dengan klinik medis $\mathrm{NH}$, memberikan bantuan pelayanan kesehatan maupun obat-obatan kepada masyarakat tidak mampu.

YNHS memang mengelola wakaf produktif dengan cara kreatif, YNHS mengajak masyarakat binaan untuk mengikuti kajian rutin, setelah itu memberikan bantuan dana untuk modal usaha bagi yang rutin mengikuti kajian, sehingga bisa disimpulkan selain memperbaiki taraf ekonomi juga memperbaiki tingkat religiusitas masyarakat.

Dalam Al Quran surah Al-hajj 22: 77 yang berbunyi :

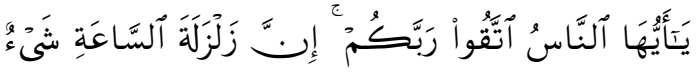

$$
\begin{aligned}
& \text { عَظِيمُ }
\end{aligned}
$$

Artinya :"Hai orang-orang yang beriman, ruku'lah kamu, sujudlah kamu, sembahlah Tuhanmu dan perbuatlah kebajikan, supaya kamu mendapat kemenangan." (Q.S. Al-hajj 22: 77).

Ayat diatas menjelaskan tentang perintah Allah SWT kepada umatNya untuk menegakkan sholat dan berbuat kebaikan. Kebaikan yang dimaksud adalah melaksanakan wakaf. Ketika seseorang melaksanakan wakaf maka apa yang diwakafkan akan memberikan manfaat untuk umat, maka inilah letak kemenanggannya, orang yang berwakaf akan terus mendapatkan pahala yang mengalir.

Potensi dari wakaf produktif memang sangat besar jika mampu dikelola dengan baik. Namun lebih baik apabila dana wakaf ini dikelola oleh lembaga yang professional dan diinvestasikan di sektor real sehingga dana dari wakaf ini dapat dimanfaaatkan di berbagai sektor, terutama di sektor ekonomi produktif demi melangsungkan tujuan wakaf yaitu kemaslahatan umat.

\section{Hambatan Dalam Pengelolaan Wakaf Produktif}

Dalam

pelaksanaannya

pengelolaan wakaf produktif juga menemui kesulitan, hambatan yang sering dihadapi YNHS adalah pola pikir masyarakat yang masih salah, yaitu tidak adanya niatan untuk mandiri. Selain itu dana yang berlebihan juga menjadi kendala, akibat dari terbatanya jumlah penerima manfaat program.

YNHS telah mengelola wakaf produktif dengan baik. Wakaf disalurkan kepada masyarakat yang kurang mampu dengan tujuan menjadikan masyarakat tidak hanya berperilaku konsumtif namun juga mandiri. Selain itu YNHS melakukan pemberdayaan keimanan dalam setiap program pengelolaan wakaf produktifnya, dengan melakukan pengajian rutin bagi setiap anggota penerima wakaf yang bertujuan dapat semakin meningkatkan keimanan dan mental yang baik sehingga semakin amanah dalam mengelola dana bantuan tersebut. Jika hal tersebut berlangsung dengan baik dengan 
sendirinya akan semakin meningkatkan perekonomian atau dengan kata lain misi pemberdayaan ekonomi bagi masyarakat tidak mampu sukses dilakukan. Karena pemanfaatan wakaf produktif bertujuan untuk meningkatkan kemaslahatan masyarakat dengan memanfaatkan secara terus menerus benda yang diwakafkan bagi kesejahteraan umat. AlQuran Surah Al-Maun ayat 1-7 memerintahkan kita untuk mengasihi orang miskin.

YNHS menyalurkan dana wakaf produktif untuk kebutuhan modal usaha bagi masyarakat yang membutuhkan, dengan tujuan agar masyarakat lebih mandiri. Peminjaman dana tersebut tidak dikenakan bunga dan besarnya angsuran disesuaikan dengan kemampuan peminjam, tidak ada syarat apapun untuk dapat melakukan peminjaman dana di YNHS, hanya perlu mendaftar sebagai peserta dan bersedia mengikuti kajian rutin yang diadakanoleh YNHS. Strategi pengelolaan wakaf yang baik perlu diciptakan untuk mencapai tujuan wakaf sebagai keadilan sosial. Wakaf sebaiknya dikelola dengan baik dan diinventasikan kedalam berbagai jenis investasi, sehingga hasilnya dapat dimanfaatkan demi kepentingan kalangan umum (Agustianto, 2010:72).

Secara umum tidak terdapat ayat Al-Quran yang menerangkan konsep wakaf secara jelas, namun para ulama menerangkannya dalam konsep keumuman dalam Surah Al Baqarah ayat 267. Program-program yang dimiliki oleh
YNHS telah sesuai dengan rencana dan target, namun hanya satu masalah yang sampai saat ini belum terselesaikan yaitu masih banyaknya dana yang belum bisa tersalurkan.

\section{Tujuan Pengelolaan Wakaf Produktif}

Pengelolaan wakaf produktif memiliki tujuan yang salah satunya menurut Agustianto (2010:72) adalah kemajuan kesejahteraan umum lainnya yang tidak bertentangan dengan syariah. Tujuan pengelolaan wakaf produktif oleh YNHS adalah supaya masyarakat menjadi lebih mandiri secara ekonomi, sedangkan untuk tujuan besarnya adalah untuk mengentaskan kemiskinan dan pemerataan perekonomian di seluruh Indonesia, wakaf produktif memiliki orientasi atau peluang di masa depan. Alqardhawi mengatakan bahwa yang dimaksud orientasi kedepan itu tidak hanya berpaku terhadap tujuan hukum syariah serta sebab tujuan syariah generasi sekarang, tetapi juga memperhatikan generasi selanjutnya, dimana menjaga keturunan adalah salah satu tugas pokok yang harus diperhatikan. Dalam Al-quran telah dijelaskan pada surat Al-Hasyr ayat 7. Pengelolaan wakaf tersebut dilakukan di beberapa bidang seperti bidang dakwah, sosial, kesehatan, pendidikan, dan ekonomi. sosialiasi yang dilakukan YNHS melalui berbagai cara, baik secara langsung maupun tidak langsung. Sosialisasi langsung dilakukan melalui koordinator yang telah dipilih pada setia program, sedangkan sosialisasi tidak 
langsung melalui media spanduk, brosur, iklan dan lain-lain.

Untuk meminimalisir macet usaha yang kemungkinan terjadi pada penerima bantuan dana, YNHS melakukan pencegahan awal yaitu dengan mendidik mental mereka terlebih dahulu dengan memperkaya pengetahuan agama melalui pengajian rutin yang dilakukan sehingga semakin amanah dalam menjalankan usahanya serta memberikan strategi-strategi dalam meningkatkan keuntungan usaha. Jadi, sangatlah penting mengubah pola pikir umat serta sinergitas ulama dan umara untuk menjadikan wakaf produktif. Salah satu cara untuk mengubahnya adalah melalui bentuk sosialisasi dan pelatihan pengelolaan ekonomi wakaf yang didukung oleh dana yang memadai, terjadwal, dan terencana.

Pengelolaan dana wakaf produktif diperlukan pengawasan yang berkesinambungan. Langkah pengawasan yang dilakukan oleh YNHS adalah dengan mengadakan laporan setiap bulan tentang besarnya keuntungan dan kerugian yang dialami oleh anggota binaan program wakaf produktif, sehingga pihak YNHS bisa mengawasi jalannya program dengan rutin. YNHS memiliki harapan dengan pengelolaan wakaf produktif ini ummat lebih produktif dan mandiri secara ekonomi tanpa harus meninggalkan kewajibannya sebagai ummat Islam. Selain pengawasan yang dilakukan secara berkesinambungan, YNHS melakukan pengelolaan wakaf produktif sepenuhnya dilakukan sendiri tanpa bantuan pihak lain. Mulai dari penerimaan, menyimpan, mengelola dan menyalurkan ke programprogram wakaf produktif yang sudah direncanakan dilakukan secara mandiri oleh pihak YNHS.

YNHS memiliki 130 santri penghafal Al-Quran, 107 mahasiswa penghafal AlQuran, 88 santri sekolah anak sholeh dan 763 orang GENPRES (Generasi Prestasi). Untuk program pemberdayaan ekonomi warga YNHS telah memfasilitasi 3 sumber air bersih, 164 layanan ambulance, 191 TAFAKUR, 1074 pemberdayaan ekonomi dhuafa, 3856 MATABACA, 16.564 pasien klinik, 6842 anak program Sayang, 556 Bunda Yatim, 5038 program Ibuqu, 112 orang jamaah tetap muallaf centre, 2726 jamaah rutin dakwah centre dan 266 orang program mendampingi rohani ibu hamil (Majalah Nurul Hayat, April 2016). YNSH merasa telah ikut berperan serta dalam pemberdayaan perekonomian masyarakat, hal tersebut dibuktikan dengan program pembinaan masyarakat dari tingkat ekonomi kurang mampu yang dimandirikan secara financial oleh YNSH melalui pemberian dana untuk modal usaha.

YNHS menganut pengelolaan wakaf produktif dengan sistem almudharabah (trust financing, trust investment) yakni dengan perjanjian bagi hasil keuntungan perniagaan. Akad ini adalah kerjasama usaha diantara dua pihak, dimana pihak pertama sebagai penyedia modal penuh, dan pihak kedua 
Anas, et al/Jurnal Ekonomi Syariah Teori dan Terapan Vol. 4 No. 3 Maret 2017: 253-268; WAKAF PRODUKTIF DALAM PEMBERANTASAN KEMISKINAN MELALUI PEMBERDAYAAN EKONOMI DI YAYASAN NURUL HAYAT SURABAYA

adalah sebagai pengelola. Dalam pengelolaan wakaf produktif pihak pertama bertindak sebagai nadhir yang akan menyerahkan seluruh modal kepada pengelola atau mudharib. Keuntungan yang diperoleh dibagi sesuai kesepakatan, keuntungan ini yang kemudian ditasharufkan sesuai tujuan wakaf.

\section{Program Pemberdayaan Ekonomi YNHS}

YNHS memiliki dua program unggulan untuk ikut dalam pemberdayaan perekonomian masyarakat yaitu program Matabaca dan Bunda Yatim. MATABACA (Majelis Ta'lim Abang Becak), memberikan bantuan kepada abang becak, baik dari segi ekonomi maupun pengetahuan agamanya, sedangkan program Bunda yatim, memberikan bantuan bagi janda yang tidak mampu dalam bentuk modal usaha. Banyak strategi yang dipergunakan YNHS dalam mensukseskan program pemberdayaan perekonomian tersebut

Strategi yang diterapkan oleh YNHS telah sesuai dengan konsep yang dipaparkan oleh Anggito (2000:74), dimana langkah-langkah nyata dan kongkrit harus diupayakan agar pertumbuhan ekonomi berlangsung secara cepat. Strategi berpusat pada upaya mendorong percepatan perubahan struktural yang selanjutnya dapat memperkuat kedudukan dan peran ekonomi masyarakat. Pemberdayaan ekonomi umat secara proposional sama dengan memberdayakan ekonomi rakyat. Pemberdayaan masyarakat menjadi tema sentral bagi pembangunan ekonomi.
YNHS sangat efektif dalam meringankan beban ekonomi masyarakat. Islam menganjurkan untuk memperhatikan kesejahteraan masyarakat. Hal ini dibuktikan dengan banyaknya hadist tentang tolong menolong dan membantu kehidupan orang lain terutama orangorang yang benar-benar membutuhkan pertolongan dan orang yang tidak berdaya, menyenangkan orang yang sedih atau susah. Larangan berbuat dzolim serta anjuran mencari rezeki yang halal. Anjuran-anjuran ini merupakan indikasi untuk menjadikan pengelolaan wakaf bermanfaat secara makro dan produktif.

\section{Pendapatan Usaha dan Pengembangan Modal}

Wakaf produktif memiliki jangka profit yang lebih panjang dan luas sehingga wakaf produktif mampu digunakan untuk kepentingan sarana pembangunan umat di berbagai bidang, seperti jaminan sosial, pendidikan, kebudayaan, ekonomi masyarakat, kesehatan dan lainnya.

Hambatan Pengelolaan Wakaf Produktif Dalam Pemberdayaan Ekonomi

Dalam perjalanannya YNHS mengakui bahwa mengalami hambatan dalam pengelolaan wakaf produktif dalam upaya ikut serta dalam pemberdayaan ekonomi, salah satu hambatan tersebut adalah mindset masyarakat sendiri yang masih belum maju. 
Anas, et al/Jurnal Ekonomi Syariah Teori dan Terapan Vol. 4 No. 3 Maret 2017: 253-268; WAKAF PRODUKTIF DALAM PEMBERANTASAN KEMISKINAN MELALUI PEMBERDAYAAN EKONOMI DI YAYASAN NURUL HAYAT SURABAYA

Oleh karena itu pengaturan wakaf produktif sangat dibutuhkan agar jelas dan tidak menghambat dalam pengelolaannya. Maka dari itu, diharapkan bahwa wakaf produktif diperlukan sebuah undang-undang untuk membatasi dan mengatur regulasinya.

Antusiasme masyarakat terhadap program pengelolaan wakaf produktif untuk pemberdayaan ekomomi sangatlah besar, hal tersebut dibuktikan dengan harapan masyarakat kepada YNHS untuk terus membantu masyarakat tidak mampu lainnya. Akibat pentingnya pemberdayaan wakaf di Indonesia menurut Agustianto (2010:29) yaitu angka kemiskinan di Indonesia masih tinggi, kesenjangan yang tinggi antara penduduk kaya dan miskin, Indonesia memiliki jumlah penduduk Muslim terbesar, sehingga wakaf memiliki potensi yang besar untuk dikembangkan. Sejumlah masalah tersebut tidak semua mudah untuk diselesaikan dalam perekonomian nasional. Butuh keseriusan dan niat yang tinggi serta usaha yang lebih dalam penyelesaiannya sehingga diharapkan pengelolaan dana wakaf akan menjadikan sektor ekonomi yang strategis. Pengelolaan wakaf dengan baik dan benar dapat memberikan manfaat yang luar biasa bagi kemaslahatan umat. Wakaf bisa menjadi sumber ekonomi umat Islam jika dikelola dengan ilmu pengetahuan yang matang dan sesuai dengan kriteria serta syariat Islam.

\section{KESIMPULAN}

Berdasarkan hasil analisis data dan pembahasan pada bab sebelumnya, maka penelitian ini dapat diambil kesimpulan sebagai berikut:

1. Wakaf secara produktif yang dilakukan oleh Yayasan Nurul Hayat Surabaya dikelola dibawah naungan BMT Pilar Mandiri Nurul Hayat. Wakaf produktif yang dikelola ini berupa wakaf uang berupa modal untuk mendanai dan membantu masyarakat miskin daerah Surabaya. Pengelolaan wakaf oleh BMT Pilar Mandiri yaitu dengan melakukan sosialisasi dengan mengadakan pengajian rutin di tiap kawasan dengan tingkat perekonomiannya masih rendah. Adanya program pemberdayaan masyarakat akan menjadi tolak ukur bagi seluruh masyarakat sehingga mereka sadar dengan adanya pengelolaan wakaf secara produktif dapat menjadi bagian dari kemandirian umat.

2. Pengelolaan wakaf produktif yang dilakukan oleh Nurul Hayat memiliki manfaat jangka panjang bagi informan. Mereka dapat memiliki kemampuan untuk mengelola usahanya sendiri sehingga mereka tidak lagi bergantung pada orang lain. Mereka diharapkan tidak hanya sebagai mauquf 'alaih saja tetapi dapat menjadi wakif agar kemandirian dapat terwujud yang menjadi tujuan utama dari Nurul Hayat dalam pengelolaan wakaf secara produktif ini. Dari bantuan yang diberikan baik dari finansial maupun pelatihan mental oleh 
Nurul Hayat, para informan dapat meningkatkan kesejahteraan dan kualitas hidup mereka.

3. Temuan yang didapat dari penelitian ini antara lain dari sosialisasi yang dilakukan oleh Nurul Hayat dengan melakukan pengajiaan rutin bagi para anggota binaan nya, mereka dapat memiliki motivasi dan juga mental yang baik sehingga ketika mereka akan memiliki rasa tanggung jawab.

\section{DAFTAR PUSTAKA}

Abimanyu, Anggito. 2000. "Pemulihan Ekonomi Indonesia dan Pemulihan Ekonomi Umat", dalam Amin Abdullah, dkk., Merentas Jalan Baru Ekonomi Muhammadiyah. Yogyakarta: PT. Tiara Wacana.

Agustianto. Wakaf Uang dan Peningkatan Kesejahteraan Umat (Artikel Zona Ekonomi Islam), di publikasikan pada Agustus, 2010.

Al-Qur'an dan Terjemahannya. 1998. Mushaf Al-Qur'an Terjemahan. Departemen Agama Rl. Semarang: Karya Toha Putra

Antonio, Muhammad Syafi'i. 2002. Bank Syari'ah sebagai Pengelola Dana Wakaf (Makalah Workshop Internasional, "Pemberdayaan Ekonomi Umat Melalui Wakaf Produktif", di Wisma Haji Batam, 7-8 Januari), hal. 4.

Dahwan. 2008. Pengelolaan Benda Wakaf Produktif. Yogyakarta: IAIN Sunan Kalijaga Yogyakarta. Jurnal Aplikasi Ilmu-ilmu Agama, Vol. IX, No. 1: 71-85

Direktorat Pemberdayaan Wakaf dan Direktorat Jenderal Bimbingan Masyarakat Islam (Dirjen Bimas Islam). 2007. Pedoman Pengelolaan Wakaf Uang. Jakarta, hal 14 \& 21

Mubarok, Jaih. 2008. Wakaf Produktif. Bandung: Simbiosa Reakatama Media
Hadi, A. Choirul. 2009. Peluang Wakaf Produktif untuk Pembiayaan Pendidikan Islam. Jurnal Turats, Vol. 5, No. 1, Juni 2009

Hafidhuddin, Didin. 2007. Wakaf Uang Dalam Pandangan Syariat Islam, Kumpulan Hasil Seminar Perwakafan, Bimas dan Haji DEPAG RI, Jakarta, Hal : 161

Halim, Abdul. 2005. Hukum Perwakafan di Indonesia. Ciputat: Ciputat Press, hal.7

Isfandiar, Ali Amin. 2008. Tinjauan Fiqh Muamalat dan Hukum Nasional tentang Wakaf di Indonesia. UIN Sunan Kalijaga Yogyakarta. Jurnal Ekonomi Islam vol II No.1

Lubis, Suhrawardi K. dkk. 2010. Wakaf dan Pemberdayaan Umat. Jakarta: Sinar Grafika

Mubyarto. 1997. Ekonomi rakyat, program IDT dan Demokrasi Ekonomi Indonesia. Yogyakarta: Aditya Media, hal 37

Nuwairah, Nahed. 2009. Pemberdayaan Ekonomi Umat Melalui Wakaf. Jurnal Kajian Islam, Vol.1 No.1. Banjarmasin: IAIN Antasari

Patton, Michael Quinn. 1987. Triangulasi dalam Moleong (Ed.). Metode Penelitian Kualitatif Edisi Revisi (Hal 327). Cetakan ke-29. Bandung: PT. Remaja Rosdakarya

Qardhawi, Yusuf Al, 1997, Fiqih Peradaban: Sunnah Sebagai Paradigma IImu Pengetahuan, Penerjemah Faizah Firdaus. Surabaya: Danakarya

Undang-Undang Republik Indonesia Nomor 41 Tahun 2004.

Yin, Robert K. 1998 \& 2009. Studi Kasus: Desain dan Metode, Terjemahan. Jakarta: PT Grafindo Persada 